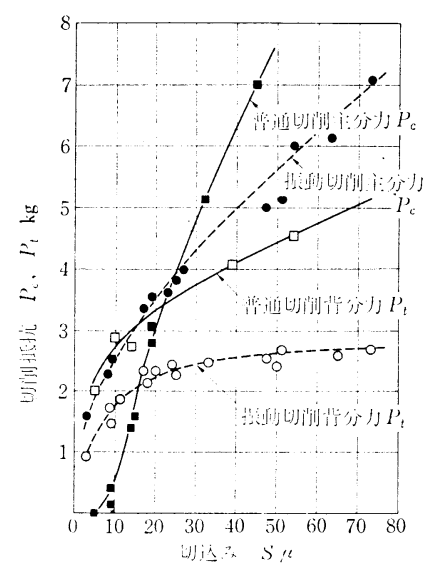

振動切削条件: $f=100 \mathrm{~Hz}, a=0.20 \mathrm{~mm}, v=0.47 \mathrm{~m} / \mathrm{min}$ $\alpha=10^{\circ}, \operatorname{BsBM} 2, w=1.0 \mathrm{~mm}$, 湿式二次元切削

図 12 切込みと切削抵抗の関係

これらの結果法，零位瞬間振動切削機構によってなさ れ，しかも被削材の全周にわたって規則的にかっ円滑に おこなわれたためにえられたものと考える。

\section{7. 結 論}

振動切削におけるパルス状の背分力 $P_{t}$ が $\omega_{n}, \nu, k$ の被削材に作用与るときの被削材の水平方向の動的变位 を表わす理論式を明らかにすることができた。 そして振 動切削には, 切削現象を安定させる零位瞬間振動切削機

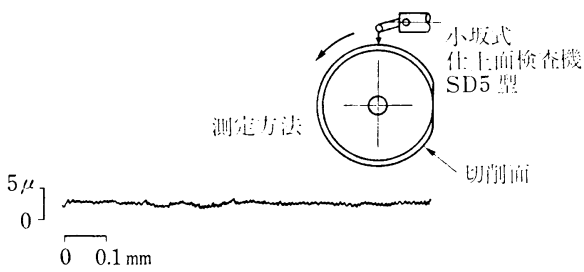

図 13 什上面あらさの一例

構と不安定な共振現象に近い切削機構があることを解明 した. 本報の $\omega / \omega_{n}<1$ の振動切削加工では $\omega / \omega_{n}$ が整数 比にならないような切洌条件を選定することが，今まで に明らかにした $v \leqq v_{c} / 3$ に加えて重要な因子となること を究明した。なお引続いて $\omega / \omega_{n}>1$ の場合の解析をお こなう予筀である。

\section{参 考 文 献}

1) 限部㳯一郎: 超音波切削機構の解析, 日本機械学 会 論文 集, 27, 181 (1961-9).

2) H. E. Meritt: Theory of Self-Excited Machine Tool Chatter, Trans. ASME, Ser. 87, 4 (1961-11).

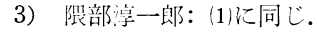

4）噮部浫一郎: 同上.

5）陮部泻一郎：同上.

6) R. S. Hahn: Metal-Cutting and Its Elimination, Trans. ASME, 75 (1953-8).

7) 山本 明，中村 示：微小切削に打ける切削開始の条件に ついて,切れ刃丸みを変化した二次元バイトによる実験, 精 密機械, 34, 5 (1968-5).

\title{
正 誤表
}

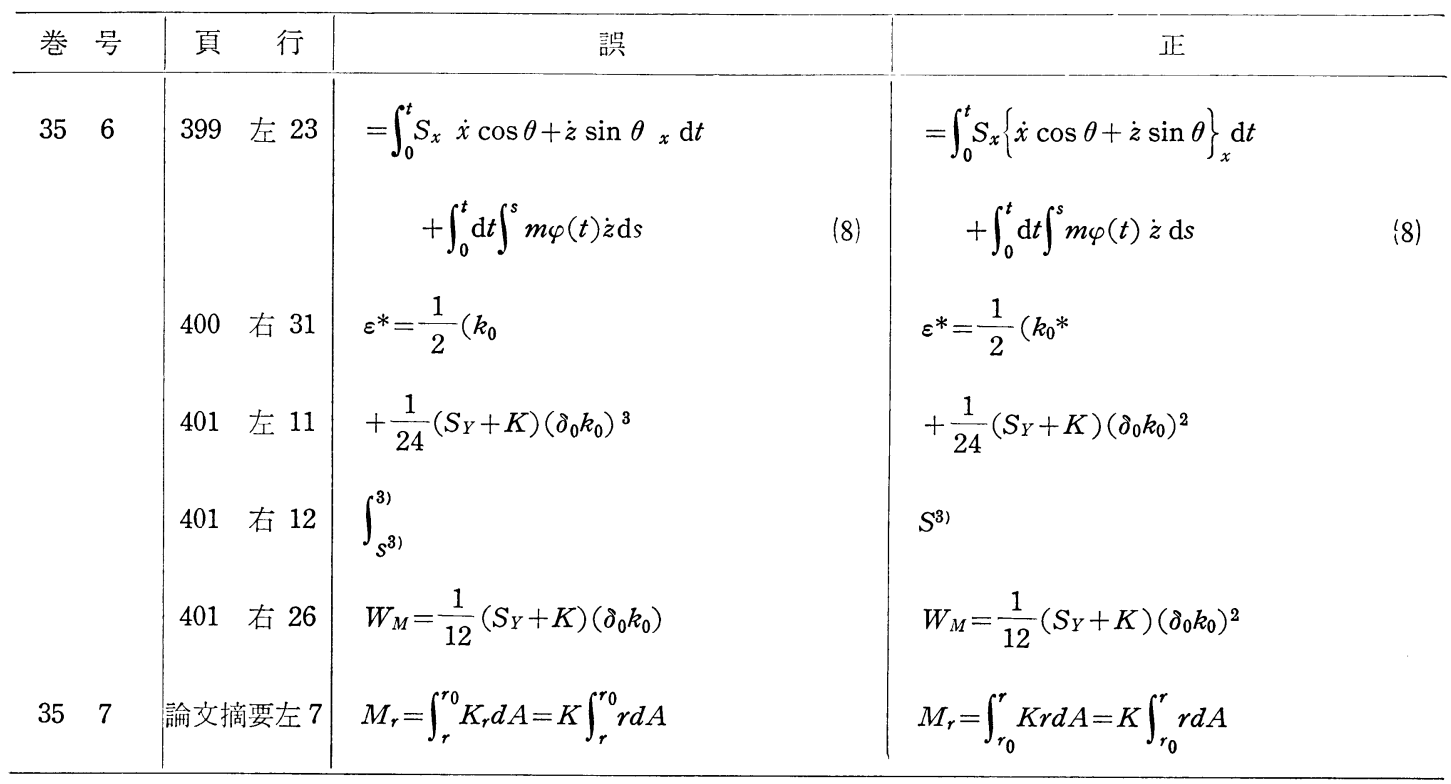

